\title{
Needs Assessment for the Development of Entrepreneurship Curriculum for a Master's Degree Program
}

\author{
Aree Naipinit $^{1}$, Thongphon Promsaka Na Sakolnakorn ${ }^{2} \&$ Patarapong Kroeksakul $^{3}$ \\ ${ }^{1}$ Faculty of Management Science, Khon Kaen University, Khon Kaen, Thailand \\ ${ }^{2}$ Institute for Peace Studies, Prince of Songkla University, Hat Yai Campus, Thailand \\ ${ }^{3}$ Faculty of Environmental Culture and Ecotourism, Srinakharinwirot University, Bangkok, Thailand \\ Correspondence: Aree Naipinit, Faculty of Management Science, Khon Kaen University, Khon Kaen, 40002, \\ Thailand. E-mail: arekul@kku.ac.th
}

Received: April 28, 2014 Accepted: May 15, 2014 Online Published: June 24, 2014

doi:10.5539/ass.v10n14p179 URL: http://dx.doi.org/10.5539/ass.v10n14p179

\begin{abstract}
The objective of this study is to study the opinion of entrepreneurs toward an entrepreneurship degree, to study the opinion of bachelor's degree students toward a master's degree in entrepreneurship, and to study the guideline for a master's degree in an entrepreneurship program. In this study, we used the quantitative method within the questionnaire provided to entrepreneurs and bachelor's degree students, and we analyzed the results using mean and standard deviation. We also utilized a qualitative method using small group discussion by inviting five academics to discuss the guidelines for a master's degree in an entrepreneurship program. The results of this study show that the entrepreneurial skills most required are communication and collaboration, the skill of teamwork is higher amongst graduates from master degree programs, and that most bachelor degree students who wish to study in the graduate program think about job opportunities first (in both the public and private sector) and hope that graduate study will increase their knowledge, skills, experience from knowledge and knowledge-sharing in class, and will result in a new way of thinking. In addition, problem-based learning and active learning are very important for a master's degree program.
\end{abstract}

Keywords: needs assessment, entrepreneurship curriculum, master's degree program

\section{Introduction}

Education leads to opportunity. Therefore, business school offers opportunities, particularly through its Master of Business Administration (MBA) degree, including the enhancement of the careers, measured mostly in terms of the salary of graduates (Pfeffer \& Fong, 2004). Business school develops critical thinking (Martin, 2002) and leads to a profession of management (Trank \& Rynes, 2003). In addition, graduates can be eligible for a managerial position with the skills required to run a business. An MBA degree will benefit graduates in terms of career and personal growth. There are career benefits, including career advancement, career change, and gaining more confidence to start a business (Australian Institute of Business, 2012).

With the growing importance of entrepreneurship, a master's degree program in entrepreneurship is very important. A master's degree program in entrepreneurship prepares students to become business professionals who are proficient in finance, management, marketing and promotion, business law, global business trends, and other areas of operation. Many entrepreneurship programs stress the importance of leadership and management through business communication and relations. With a master's degree in entrepreneurship, business professionals can establish their own business, provide operational advice or manage existing businesses. Both Master of Science and Master of Business Administration (MBA) programs in entrepreneurship are offered (Mertl, 2014).

However, business schools face several problems, including growing competition, lack of research education and teaching, and executive education offered by an expanding set of providers (Pfeffer \& Fong, 2004). Today, the power of the MBA is not so certain. Many in corporate America and academia say that the degree that once defined bright, snappy leadership now symbolizes a discipline that has lost touch with the business world. They argue that MBA programs have become too focused on research and those in-house training at large firms has more practical applications. They claim the programs have failed to create the types of leaders who can deal with 
globalization, and some say they don't develop leaders at all but simply create functionaries. Other critics think that a focus on profit and share value, rather than on ethics and sustainability, fostered the type of narrow-minded thinking that led to the fall of Enron and the last recession (Entrepreneur, 2012). In addition, Kirby (2004) stated that educational institutions need to change the process of learning to enable their students to develop their right-brain entrepreneurial capabilities as well as their left-brain analytical skills and that business schools need to weaken the thought processes of learning so as to encourage and stimulate the entrepreneurial imagination.

Khon Kaen University, Thailand's public research university was the first university established in the northeast region of Thailand and remains the oldest and largest university within the region. The university is a central hub of education in northeast Thailand and is an internationally recognized university in Asia. Khon Kaen University offers a wide range of programs: its comprehensive academic program offers 105 undergraduate majors, along with 129 master's degree programs and 59 doctoral programs. Khon Kaen University was ranked 21st in South East Asia by Time Higher Education in 2009 and 4th in Thailand by The Office of Higher Education Commission, Thailand. Khon Kaen University has two business schools, the Faculty of Management Science and the College of Graduate Study in Management. Both fall within the master of business administration program; however, both business schools do not yet have a master's degree program in entrepreneurship.

Entrepreneurship and entrepreneurship education have been discussed frequently in the past few years and promoted in all the national and European educational and political reform strategies. Teaching entrepreneurship is a challenge for most of the professors from non-business faculties, where the development of soft skills should be combined with a proactive approach of changing mindsets and attitudes (Martin \& Iucu, 2014). Entrepreneurship as a skill and process is increasingly being taught as a part of various university educational programs (Al-Atabi \& DeBoer, 2014). Curriculum development for a master's degree in entrepreneurship is very important for a university to extend knowledge to people and community, and then the new knowledge can give more ideas to students who can finish a master's degree to bring their knowledge to the development of their organization. So, within this paper, we will present the study of needs assessment for the development of entrepreneurship curriculum for a master's degree program, and this study will lead to the development of the curriculum of the master's degree in entrepreneurship for the Faculty of Management Science, Khon Kaen University, Thailand.

\section{Objectives}

To study the opinion of entrepreneurs toward an entrepreneurship degree

To study the opinion of bachelor's degree students toward a master's degree in entrepreneurship

To study the guidelines for a master's degree in an entrepreneurship program

\section{Methodology}

The location of this study is within the northeast region of Thailand. In this study, researchers utilized both a quantitative and qualitative method. Using the quantitative method, researchers provided 60 questionnaires to entrepreneurs by mail, and 45 questionnaires were returned. Researchers also provided 400 questionnaires to bachelor's degree students, by mail but only 220 were returned. The questionnaire used the Linkert scale and offered five answers: strongly agree, agree, moderately agree, disagree, and strongly disagree. The closed questionnaire was interpreted by dividing the question scales into a 5-point scale as higher, high, moderate, low, and lowest $(5.00-4.5,4.49-3.50,3.49-2.50,2.49-1.50$, and 1.49-1.00), and researchers analyzed this data using mean and standard deviation.

In addition, researchers used the qualitative method using a small group discussion by inviting five academics to discuss the guidelines of a master's degree in entrepreneurship, and researchers used content analysis and descriptive analysis to analyze the data.

\section{Literature Reviews}

The most fundamental reason for thinking about entrepreneurship at the grass roots is to find sustainable solutions to overcoming the injustices of poverty, which is evidenced by malnutrition, low life expectancy, indifferent educational attainment, poor access to water, inadequate health care, and exclusion from the benefits of economic and technological progress (The Centre for Entrepreneurial Learning, University of Cambridge, 2009). The National Content Standards for Entrepreneurship Education (2004) stated that entrepreneurship education can positively impact a learner at all levels in a wide number of contexts. Entrepreneurship is a key driver of our economy. Wealth and a high majority of jobs are created by small businesses started by entrepreneurially minded individuals, many of whom go on to create big businesses. People exposed to entrepreneurship frequently express that they have more opportunity to exercise creative freedoms, higher 
self-esteem, and an overall greater sense of control over their own lives. As a result, many experienced business people, political leaders, economists, and educators believe that fostering a robust entrepreneurial culture will maximize individual and collective economic and social success on a local, national, and global scale.

Entrepreneurship education benefits individuals not just by helping them launching a business, but by instilling the entrepreneurial mindset that allows individuals to excel in whatever avenue they choose to pursue. Entrepreneurial education improves academic performance and increases problem-solving and decision-making skills. In addition, entrepreneurship education improves interpersonal relationships, teamwork skills, money management, and public speaking skills. It also increases job readiness and job preparedness (Busko, 2013). Entrepreneurial education is one of the best ways to support growth and generate jobs. Students who receive entrepreneurship education are not only more likely to be employed, but also more likely to start their own companies (Enterprise \& Industry Magazine, 2013). It is very important to teach entrepreneurship outside the schools, to bring students into the world where business happens (Washington Post, 2014).

Development of entrepreneurship education and curriculum is very important for a region, if that region does not yet have a university or school teaching both bachelor's degree and master's degree in entrepreneurship. Curriculum is the foundation of the teaching-learning process. The development of programs of study, learning and teaching resources, lesson plans and assessment of students, and even teacher education are all based on curriculum (Pree, 1987). The curriculum development process systematically organizes what will be taught, who will be taught, and how it will be taught. Each component affects and interacts with other components. For example, what will be taught is affected by who is being taught (e.g., their stage of development in age, maturity, and education). Methods of how content is taught are affected by who is being taught, their characteristics, and the setting (Natural Resources Management and Environment Department, United Nations, 1996). In addition, Cai and Cirillo (2014) stated that the findings from curriculum analyses can have broad implications for curriculum developers, textbook analysis provides reliable feedback for future revisions. In addition, for classroom teachers and district leaders, the findings from curriculum analysis may help them select which textbook series to adopt for their schools.

The curriculum development process includes the design, development, implementation, and evaluation of curricula. In this paper, the focus is on the design process by using research on needs assessment for the development of entrepreneurship curriculum for a master's degree program. The conceptual framework of this study is shown in Figure 1.

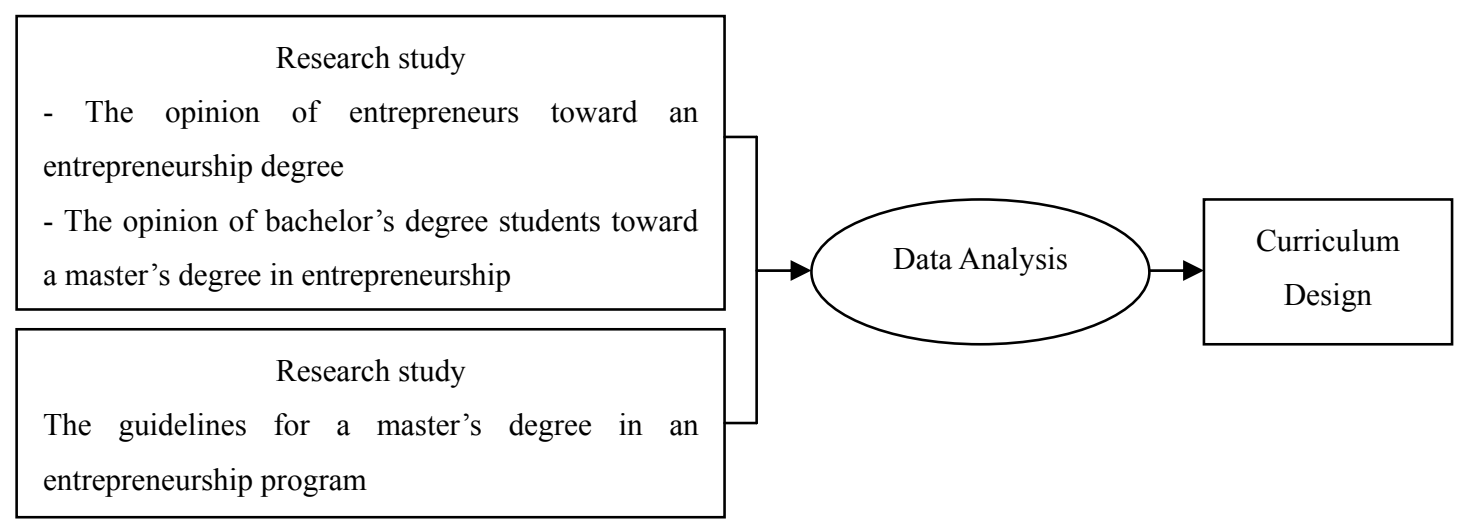

Figure 1. Conceptual framework

\section{Results}

\subsection{The Opinion of Entrepreneurs}

From the study, most entrepreneurs who answered the questionnaire have revenue between $\$ 300-\$ 1,000$ USD per month (40\%), lower than $\$ 300$ USD per month (33\%), between $\$ 1,000-\$ 1,700$ USD per month $(20 \%)$, and more than $\$ 1,700$ USD per month (3\%). The opinion of entrepreneurs toward students in the entrepreneurship degree is shown in Table 1. 
Table 1. The opinion of entrepreneurs

\begin{tabular}{|c|c|c|c|}
\hline \multirow{2}{*}{ The opinion of entrepreneurs toward the students in an entrepreneurship degree } & \multicolumn{3}{|c|}{ Opinion level } \\
\hline & $x$ & S.D. & Level \\
\hline Skill in communication and collaboration & 4.600 & 0.629 & Higher \\
\hline Skill of teamwork & 4.756 & 0.620 & Higher \\
\hline Skill in creative thinking & 3.911 & 0.769 & High \\
\hline Honest, working on time, and respecting other people & 4.933 & 0.291 & Higher \\
\hline Have responsiveness in critical work & 3.756 & 0.860 & High \\
\hline Skill in English for communication & 4.267 & 0.786 & High \\
\hline Can communicate to foreign customers & 3.533 & 0.897 & High \\
\hline Uses research to solve problems & 4.089 & 0.950 & High \\
\hline Can analyze the internal and external marketing & 3.889 & 1.110 & High \\
\hline The curriculum related to entrepreneurship & 4.178 & 1.028 & High \\
\hline $\begin{array}{l}\text { Students have the opportunity to conduct fieldwork and use case studies in the field of } \\
\text { entrepreneurship }\end{array}$ & 3.911 & 0.877 & High \\
\hline Lecturer and faculty staff have experience and knowledge in the entrepreneurial field & 3.867 & 0.763 & High \\
\hline $\begin{array}{l}\text { The master's degree program can offer particular knowledge to students, such as all management } \\
\text { of SMEs, OTOP, large enterprises, and all aspects of a business organization }\end{array}$ & 3.689 & 0.902 & High \\
\hline Have observed study, both locally and overseas; for example, visiting overseas entrepreneurships & 3.733 & 0.768 & High \\
\hline Students can use system-thinking for management & 4.067 & 0.892 & High \\
\hline Students can make a proposal for a business project & 3.933 & 0.757 & High \\
\hline $\begin{array}{l}\text { The curriculum of a master's degree should to be an international program for supporting the } \\
\text { ASEAN community in } 2015\end{array}$ & 4.400 & 0.663 & High \\
\hline This master's degree program has teachers in both the thesis program and coursework program & 3.578 & 0.699 & High \\
\hline $\begin{array}{l}\text { A master's degree program in entrepreneurship should have to develop the curriculum for Khon } \\
\text { Kaen University }\end{array}$ & 4.378 & 0.625 & High \\
\hline Total & 4.077 & 0.785 & High \\
\hline
\end{tabular}

From Table 1, the most entrepreneurial skills required are communication and collaboration, and the skill of teamwork. In addition, teamwork and collaboration skills give organizations more efficiency as opposed to individual work because cooperative work reduces workloads for all employees and can result in the sharing of knowledge and ideas and increase the potential of business.

\subsection{The Opinion of Bachelor's Degree Students Who Wish to Continue to the Graduate Program}

From the data derived from people who wish to continue to the graduate program, we provided 400 questionnaires to the target population, but only 220 were returned. From the study, we found that $77 \%$ were students from a public university and $23 \%$ were students from a private university. Most students were between 15-25 years in age, and most of the students who answered the questionnaire were studying in their final year of their degree. The opinion of bachelor's degree students who wish to continue to the graduate program is show in Table 2 .

Table 2. The opinion of bachelor's degree students who wish to continue to a graduate program in entrepreneurship

\begin{tabular}{|c|c|c|c|}
\hline \multirow{2}{*}{$\begin{array}{l}\text { The opinion of bachelor's degree students who wish to continue to a graduate program in } \\
\text { entrepreneurship }\end{array}$} & \multicolumn{3}{|c|}{ Opinion level } \\
\hline & $x$ & S.D. & Level \\
\hline After finishing a master's degree, students can gain a job & 4.659 & 0.566 & Higher \\
\hline This degree can work in both the public (government employee) and private sector & 4.709 & 0.597 & Higher \\
\hline The entrepreneurship degree can offer more knowledge to students & 3.786 & 0.894 & High \\
\hline You would like to continue studies in the entrepreneurship degree & 3.659 & 0.938 & High \\
\hline The entrepreneurship degree is suitable and a requirement of the labour market & 3.386 & 1.234 & Moderate \\
\hline $\begin{array}{l}\text { Master of business administration in entrepreneurship is suitable and a requirement of the } \\
\text { labour market }\end{array}$ & 3.577 & 1.204 & High \\
\hline Graduates from the master of business administration in entrepreneurship have more & 3.350 & 1.299 & Moderate \\
\hline
\end{tabular}




\begin{tabular}{|c|c|c|c|}
\hline \multirow{2}{*}{$\begin{array}{l}\text { The opinion of bachelor's degree students who wish to continue to a graduate program in } \\
\text { entrepreneurship }\end{array}$} & \multicolumn{3}{|c|}{ Opinion level } \\
\hline & $x$ & S.D. & Level \\
\hline \multicolumn{4}{|l|}{ employment opportunities and greater chances of receiving a higher salary } \\
\hline $\begin{array}{l}\text { Graduates from the master of business administration in entrepreneurship can be an owner of } \\
\text { business }\end{array}$ & 3.355 & 0.961 & Moderate \\
\hline $\begin{array}{l}\text { Master of business administration in entrepreneurship should have to develop the curriculum } \\
\text { for Khon Kaen University }\end{array}$ & 3.432 & 1.340 & Moderate \\
\hline The program should place an emphasis on theory & 3.059 & 1.051 & Moderate \\
\hline The program should place an emphasis on research study & 2.823 & 1.142 & Disagree \\
\hline The curriculum of the master's degree should be an international program & 3.164 & 1.400 & Moderate \\
\hline $\begin{array}{l}\text { Students have an opportunity to conduct fieldwork and case studies in entrepreneurship through } \\
\text { both local and international sightseeing }\end{array}$ & 3.264 & 1.427 & Moderate \\
\hline The curriculum of the master's degree should be a bilingual education program & 3.764 & 1.153 & High \\
\hline $\begin{array}{l}\text { The program can lead to a student opening a business or working as an employee with a higher } \\
\text { level of potential }\end{array}$ & 4.282 & 1.094 & High \\
\hline Total & 3.618 & 1.090 & High \\
\hline
\end{tabular}

From Table 2, we found that most bachelor's degree students who wish to study in the graduate program think about job opportunities in the public and private sectors first, and they hope that a graduate study will increase their knowledge, skills, experience from knowledge, and knowledge sharing in class, and will result in a new system of thinking. In addition, most respondents would like to study for their master's degree on the weekend (Saturday and Sunday), regular program (Monday to Friday) between 8:30 a.m.-6:30 p.m. (33\%), and Monday to Friday between 5:00 p.m.-8:30 p.m. (8\%). Regarding the tuition fees, the respondents suggested $\$ 650$-\$850 USD per semester (89\%), \$850-\$1,200 USD per semester (9\%), and \$1,200-\$1,500 USD per semester (2\%).

\subsection{Guidelines for Master's Degree in the Entrepreneurship Program}

The suggestions for the master's degree in entrepreneurship are as follows: first, offer problems-based learning, (i.e. case discussion) and allow students to focus on how and what they will learn. Hmelo-Silver (2004) stated that problem-based learning is an instructional method in which students learn through facilitated problem solving, which helps the students develop flexible knowledge, effective problem-solving skills, self-directed learning, effective collaboration skills, and intrinsic motivation. Second, offer active learning, i.e. class discussion, a think pair share, collaborative learning group, student debate, a case study, and so on. Bonwell and Eison (1991, p. 2) state that active learning is anything that involves students doing things and thinking about the things that they are doing. In addition, the study of Hoellwarth and Moelter (2011) showed that when instructors switched their classes from traditional instruction to active learning, student learning improved by 38 percentage points-from around $12 \%$ to over $50 \%$.

In addition, the subject course for a master's degree in entrepreneurship is entrepreneurship management, entrepreneurial marketing, entrepreneurial operations, and legal aspects of entrepreneurship, entrepreneurial finance, social business, green business, and business economics for the entrepreneur, entrepreneurial strategy, organization behavior, human resource management, and international business.

\section{Conclusion}

The study found that Khon Kaen University should launch a new master's degree program in entrepreneurship and set up the program as both a regular program (Monday-Friday) and a weekend program (Saturday-Sunday). The tuition fee is between $\$ 650$ - $\$ 850$ USD per semester. In addition, problem-based learning and active learning should also be seriously developed because in the real phenomenon, every lecturer knows about this learning issue but still lacks the necessary operations and activities. Within problem-based learning, the role of the instructor is to guide and challenge the learning process rather than strictly providing knowledge (Dolmans, De Grave, Wolfhagen, \& Van Der Vleuten, 2005), feedback, and reflection on the learning process, and group dynamics are essential components of problem-based learning. This assists in the process of creating meaning and building personal interpretations of the world based on experiences and interactions (Edens, 2000). In addition, several studies show that using active-learning activities before, rather than after, lectures or readings results in a deeper learning, understanding, and transfer of knowledge (Kapur 2010; Kapur \& Bielaczyc, 2012).

Khon Kaen University is a research-based university that can bring research and case studies into the classroom, and the demand of the population and bachelor's degree students who wish to continue with a graduate education 
is driving Khon Kaen University to develop many potential programs for supporting and developing human capital, which is a key step to improving upon the development of Thailand. However, it is not only knowledge of entrepreneurship management: the bilingual education program in both English and Thai is also very important. Many foreign businesses have come to the region, and many foreigners have also come to live in the northeast of Thailand. Thailand is going to be a member of the ASEAN community in 2015, which means that labour mobilization will occur, and many neighboring laborers' will travel to Thailand to work for a higher income, eventually presenting competition to Thai workers.

\section{Acknowledgements}

This study was financially supported by the Faculty of Management Science, Khon Kaen University, Thailand.

\section{References}

Al-Atabi, M., \& DeBoer, J. (2014). Teaching entrepreneurship using Massive Open Online Course (MOOC). Technovation, 34(4), 261-264. http://dx.doi.org/10.1016/j.technovation.2014.01.006

Australian Institute of Business. (2012). Reasons for you to upgrade your skills with an MBA. Retrieved April 22, 2014, from http://www.aib.edu.au/mba/165/reasons-for-you-to-upgrade-your-skills-with-an-mba

Bonwell, C., \& Eison, J. (1991). Active learning: Creating excitement in the classroom AEHE-ERIC Higher Education Report No. 1. Washington, D.C.: Jossey-Bass.

Busko, M. (2013). The importance of entrepreneurship education. Retrieved May 4, 2014, from http://www.venturecenterwi.com/blog/item/guest-blogger-marc-busko

Cai, J., \& Cirillo, M. (2014). What do we know about reasoning and proving? Opportunities and missing opportunities from curriculum analyses. International Journal of Educational Research, 64, 132-140. http://dx.doi.org/10.1016/j.ijer.2013.10.007

Dolmans, D. H. J. M., De Grave, W., Wolfhagen, I. H. A. P., \& Van Der Vleuten, C. P. M. (2005). Problem-based learning: Future challenges for educational practice and research. Medical Education, 39(7), 732-741. http://dx.doi.org/10.1111/j.1365-2929.2005.02205.x

Edens, K. M. (2000). Preparing problem solvers for the 21st century through Problem-Based Learning. College Teaching, 48(2), 55-60. http://dx.doi.org/10.1080/87567550009595813

Enterprise \& Industry Magazine. (2013). Entrepreneurship education key to sustainable economic upswing. Retrieved May 4, 2014, from http://ec.europa.eu/enterprise/magazine/articles/smes-entrepreneurship/ article_11079_en.htm

Entrepreneur. (2012). Is an MBA Still Necessary? Retrieved April 22, 2014, from http://www.entrepreneur.com/ article $/ 224440$

Hmelo-Silver, C. E. (2004). Problem-based learning: What and how do students learn? Educational Psychology Review, 16(3), 235-266. http://dx.doi.org/10.1023/B:EDPR.0000034022.16470.f3

Hoellwarth, C., \& Moelter, M. J. (2011). The implications of a robust curriculum in introductory mechanics. American Journal of Physics, 79(5), 540-545. Retrieved from http://ajp.aapt.org/resource/1/ajpias/v79/i5; http://dx.doi.org/10.1119/1.3557069

Kapur, M. (2010). Productive failure in mathematical problem solving. Instructional Science, 38(6), 523-550. http://dx.doi.org/10.1007/s11251-009-9093-x

Kapur, M., \& Bielaczyc, K. (2012). Designing for productive failure. Journal of the Learning Sciences, 21(1), 45-83. http://dx.doi.org/10.1080/10508406.2011.591717

Kirby, D. A. (2004). Entrepreneurship education: Can business schools meet the challenge? Education + Training, 46(8/9), 510-519.

Martin, C., \& Iucu, R. B. (2014). Teaching entrepreneurship to educational sciences students. Procedia-Social and Behavioral Sciences, 116, 4397-4400. http://dx.doi.org/10.1016/j.sbspro.2014.01.954

Martin, R. (2002). Integrative thinking: A model takes shape. Rotman Management, 6-11.

Mertl, W. (2014). Master's degree programs in entrepreneurship with course info. Retrieved April 22, 2014, from http://education-portal.com/master's_degree_programs_in_entrepreneurship.html

Natural Resources Management and Environment Department, United Nations. (1996). Curriculum development guide: Population education for non-formal education programs of out-of-school rural youth. Retrieved 
May 2, 2014, from http://www.fao.org/docrep/009/ah650e/ah650e00.htm

Pfeffer, J., \& Fong, C. T. (2004). The business school 'Business': Some lessons from the US experiences. Journal of Management Studies, 41(8), 1501-1520. http://dx.doi.org/10.1111/j.1467-6486.2004.00484.x

Pree, M. D. (1987). Chapter 1: Curriculum development processes. Retrieved May 2, 2014, from http://www. education.alberta.ca/media/6809242/d_chapter1.pdf

The Centre for Entrepreneurial Learning, University of Cambridge. (2009). Why entrepreneurship education is important for social inclusion. Retrieved May 6, 2014, from http://www.cfel.jbs.cam.ac.uk/blog/?p=131

The National Content Standards for Entrepreneurship Education. (2004). Importance of Entrepreneurship Education. Retrieved May 4, 2014, from http:/www.entre-ed.org/Standards_Toolkit/importance.htm

Trank, C. Q., \& Rynes, S. L. (2003). Who moved our cheese? Reclaiming professionalism in business education. Academy of Management Learning and Education, 2(2), 198-205. http://dx.doi.org/10.5465/AMLE.2003. 9901678

Washington Post. (2014). Can you really teach entrepreneurship? Retrieved May 4, 2014, from http:/www.washingtonpost.com/business/on-small-business/can-you-really-teach-entrepreneurship/2014/03 /21/51426de8-a545-11e3-84d4-e59b1709222c_story.html

\section{Copyrights}

Copyright for this article is retained by the author(s), with first publication rights granted to the journal.

This is an open-access article distributed under the terms and conditions of the Creative Commons Attribution license (http://creativecommons.org/licenses/by/3.0/). 